\section{EDUCATION}

Research, Innovation and Solutions on-line ${ }^{(2)}$
Electronic Journal of Research

in Educational Psychology

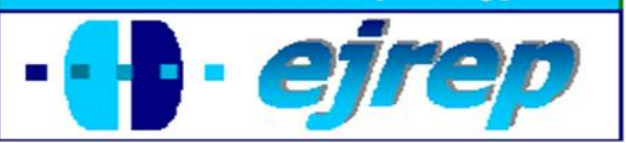

\title{
Reducing the Need for Postsecondary Remediation Using Self-efficacy to Identify Underprepared African-American and Hispanic Adolescents
}

\section{Carolyn Orange $^{1}$, Elizabeth Murakami Ramalho ${ }^{2}$,}

\author{
${ }^{1}$ Professor, Educational Psychology, University of Texas \\ ${ }^{2}$ Associate Professor, Educational Leadership, University of Texas \\ San Antonio
}

United States of America

Correspondence: Carolyn Orange, PhD 2303 Ruby Oaks San Antonio, TX 78232 USA

E-mail: carolyn.orange@utsa.edu

(C) Education \& Psychology I+D+i and Editorial EOS (Spain) 


\begin{abstract}
Introduction. Postsecondary remedial education is a major problem for Higher Education affecting retention rates, degree completion rates and cost of enrollment. Identification of students who are underprepared for managing the rigors of college and who would benefit from early intervention is necessary to reduce the need for postsecondary remediation. This study examines student perceptions of self-efficacy and use of self-regulatory behaviors as a possible indicator for need for remediation.
\end{abstract}

Method. Sixty-three $10^{\text {th }}$ and $11^{\text {th }}$ grade Texas students (52.5\% African American, $44.3 \%$ Hispanic, $3.2 \%$ others) participated in the study. Two self-regulation inventories, the SRI-HS and LASSI-HS, were administered to determine student self-efficacy and their use of self-regulatory behaviors. A Predictive Discriminant Analysis was used to successfully classify level of self-efficacy of a group of African American and Hispanic adolescents into 3 mutually exclusive groups, [high (81\%), moderate $(65 \%)$ or low $(72 \%)]$ based on scores from the two self-regulation inventories.

Results. A Kruskal-Wallis analysis revealed areas of the SRI-HS and LASSI-HS inventories where low self-efficacy African American and Hispanic students scored significantly lower than their high self-efficacy counterparts on self-reported use of self-regulatory skills and behaviors. Both inventories revealed problems in managing distractions, attitude, concentration, help-seeking, study strategies, goal setting, attention, selecting the main idea, and test strategies; important skills needed by underprepared students and would be useful in intervention. Attitude was the lowest percentile score $\left(15^{\text {th }}\right.$ percentile) for high and low self-efficacy groups. The PDA model correctly identified students (72.9\% of the grouped cases) making such a model useful for predicting students with low academic selfefficacy (72\%) to identify underprepared students; students that could benefit from self-efficacy and self-regulation intervention.

Discussion. The results support the hypothesis that students that have high self-efficacy tend to use more self-regulatory skills and behaviors than students with lower self-efficacy. This finding suggests high self-efficacy is a link to higher achievement and therefore, less likelihood of needing postsecondary remediation. Suggestions for improving student self-efficacy self-regulation and attitude in both high and low self-efficacy, underprepared students are offered to decrease the likelihood of need for post-secondary remediation.

Keywords: Underprepared students, Self-Efficacy, Self-Regulation, African American, Hispanic, Adolescent, Attitude. 


\title{
Reducir la Necesidad de Educación Compensatoria Post- secundaria al Emplear la Auto-eficacia para Identificar a los Adolescentes Afroamericanos e Hispanos menos Preparados
}

\begin{abstract}
Resumen
Introducción. La educación postsecundaria de remediación es un problema importante para la educación superior que afectan a las tasas de retención, las tasas de finalización de grado y costo de inscripción. La identificación de los estudiantes que están armonizados para la gestión de los rigores del colegio y que se beneficiarían de la intervención temprana es necesario reducir la necesidad de corrección secundaria posterior. Este estudio examina las percepciones de estudiantes de la autoeficacia y uso de conductas de autorregulación como un posible indicador de necesidad de corrección.
\end{abstract}

Método. $6310^{\text {th }}$ y $11^{\text {th }}$ grado los estudiantes de Texas (52,5\% afroamericanos, 44,3\% hispanos, 3.2\% otros) participaron en el estudio. Se administraron dos inventarios de autorregulación, el SRI-HS y LASSI-HS, para determinar la autoeficacia del estudiante y su uso de conductas de autorregulación. Se utilizó un análisis discriminante predictivo para clasificar correctamente el nivel de autoeficacia de un grupo de adolescentes afroamericanos e hispanos en 3 grupos mutuamente excluyentes, [alta (81\%), moderada (65\%) o bajo (72\%)] basado en los resultados de los dos inventarios de autorregulación.

Resultados. Un análisis Kruskal-Wallis análisis reveló áreas de los inventarios de SRI-HS y LASSIHS donde estudiantes de afroamericanos e hispanos de la autoeficacia bajos significativamente más bajo que sus homólogos de la autoeficacia altas anotaron autoinformado uso de habilidades de autorregulación y comportamientos. Ambos inventarios revelan problemas en la gestión de las distracciones, actitud, concentración, para buscar ayuda, estrategias de estudio, estableciendo metas, atención, seleccionar la idea principal y prueba de estrategias; importantes habilidades necesarias por studentsand armonizado sería útil en la intervención. Actitud fue el percentil menor puntuación $\left(15^{\text {th }}\right)$ para grupos de alta y baja autoeficacia.Los alumnos de modelo correctamente identificado PDA (72,9\% de los casos agrupados) haciendo un modelo útil para predecir los estudiantes con baja autoeficacia académica (72\%) para identificar a los estudiantes armonizados; los estudiantes que podrían beneficiarse de la intervención de la autoeficacia y la autorregulación.

Discusión. Los resultados apoyan la hipótesis de que los estudiantes que tienen alta autoeficacia tienden a usar más actitudes y comportamientos de autorregulación que los estudiantes con menor autoeficacia. Este hallazgo sugiere que una alta autoeficacia se asocia a un mayor logro y, por lo tanto, es menos probable que sea necesario un refuerzo en la post-secundaria. Se ofrecen sugerencias para mejorar la autorregulación y las actitudes de la autoeficacia para los estudiantes tanto de alta como de 
Orange, C. et al.

baja autoeficacia. Para todos los estudiantes se ofrece la posibilidad de disminuir la necesidad de refuerzo en post-secundaria.

Palabras clave: Estudiantes menos preparados, autoeficacia, autorregulación, afroamericanos, hispanos, adolescente, actitud.

Recepción: 15/11/12

Aceptación inicial: 13/02/13

Aceptación final: 14/03/13 


\section{Introduction}

The prevalence of postsecondary remedial education is a topic of national concern. Students that fail to meet minimum college readiness requirements are often required to take remedial education courses. These courses are not college-level, they receive no college credit and consequently don't count toward a college degree. Students pay tuition for these courses and the return on their investment is questionable. Most remediation courses are reading, writing and math courses.

Government officials, higher education administrators and academicians are scrambling to develop strategies to reduce the negative effects of postsecondary remediation on degree completion rates, time to degree, and the overall cost of enrollment (Bailey, 2009; Bailey, Jeong, \& Cho, 2009; Melguizo, Hagedorn, \& Cypers, 2008; Tierney \& Garcia, 2008). The annual cost to provide remedial courses at public postsecondary institutions was prohibitive and estimated at $\$ 900$ million to $\$ 1$ billion in 1993-94. Approximately $29 \%$ of first year students enroll in at least one remedial course (Breneman, 1998). The numbers have grown exponentially. By 2007-08, approximately $36 \%$ of first year students had taken at least one remedial course (NCES, 2010). African American and Hispanic adolescents are more likely to need postsecondary remediation. Only $31 \%$ of whites need remediation, whereas, $41 \%$ of Hispanics and $42 \%$ of African-American students require postsecondary remediation (NCSL, 2012).

Davis and Palmer (2010) suggest that secondary schools work to resolve academic deficiencies of underprepared (students not meeting minimum college readiness requirements) African American students early, by providing effective opportunities to correct those deficiencies. The same would be true for Hispanic students. African American high school graduates were least likely to meet the College Readiness Benchmarks; only $4 \%$ met all four. Approximately 50\% of Hispanic or African American students failed to meet any of the four Benchmarks (ACT, 2012). Many of these students are obviously underprepared for the rigors of college and the problem continues, as evidenced by the growing numbers of African American and Hispanic students needing postsecondary remediation. We contend that selfregulation and self-efficacy may have a role in the underpreparation of these students. 


\section{Self-Efficacy and Self-regulation of African American and Hispanic Students}

A careful examination of the literature reveals considerable overlap in definitions of self-regulation. For example, Zimmerman $(1989,1998)$ describes academic self-regulation as a student's self-managed process in which the student activates and sustains cognitive, behavioral and affective investment in a systematic pattern towards the attainment of specific academic goals and achievement. Orange (1999) contends that a summary of many of the definitions found in the literature, might be used to define self-regulation as a student's willingness and ability to effectively manage or direct their learning. She also identified a collection of subprocesses of self-regulation from the literature: self-monitoring, self-instruction, self-reinforcement, self-verbalization, self-judging, and self-reaction self-observation, selfevaluation self-pacing, self-motivation and self-efficacy (Bandura, 1997; Schunk, 1996; Zimmerman \& Martinez-Pons, 1990). Orange (1999) also suggests there is value in using appropriate strategies and attitudes to help students learn to sustain goal-directed behaviors and to seek assistance when necessary Self-regulation is not an inborn trait; it can be taught and acquired.

Self-efficacy, as defined by Bandura (1997), is one's belief about how well he or she can successfully complete a task. He proposes that one's beliefs about personal competency is not completely dependent on actual abilities, but rather on what one believes one can do. Thus, beliefs that people have about their abilities and capabilities to perform at various levels, influence events in their lives and affect how they feel and behave. Self-efficacy is a very important process, and it may well be one of the most important factors in self-regulation. Bandura's (1977) seminal work on self-efficacy validated the assumption that people often create and foster perceptions of their capabilities. Since Bandura's (1994) early self-efficacy research on student achievement, various researchers have replicated and validated the strong and positive influence that students' self-efficacy has on motivation and achievement (Jackson, 2002; Lane \& Lane, 2001 ; Pajares, 2003; Pajares \& Miller, 1994; Schunk, 1991).

Knowledge of inefficacious students and their areas of weakness is the key for improving the self-efficacy for all students (Fall \& McLeod, 2001 ). Students with high and low self-efficacy have varying characteristics according to Bandura (1994). He identified contrasting characteristics of high and low self-efficacy students. High self-efficacy students view difficult tasks as challenges, sets challenging goals whereas low self-efficacy students may avoid challenge, have low aspirations and set less challenging goals. High self-efficacy stu- 
dents are thought to heighten and sustain their efforts in the face of failure, whereas lower self-efficacy students may slacken their efforts or give up in the face of failure (see Figure 1 for characteristics of high and low self-efficacy students).

\section{Elements of Self-efficacy Characteristics on a High and Low Continuum} From Bandura (1994)
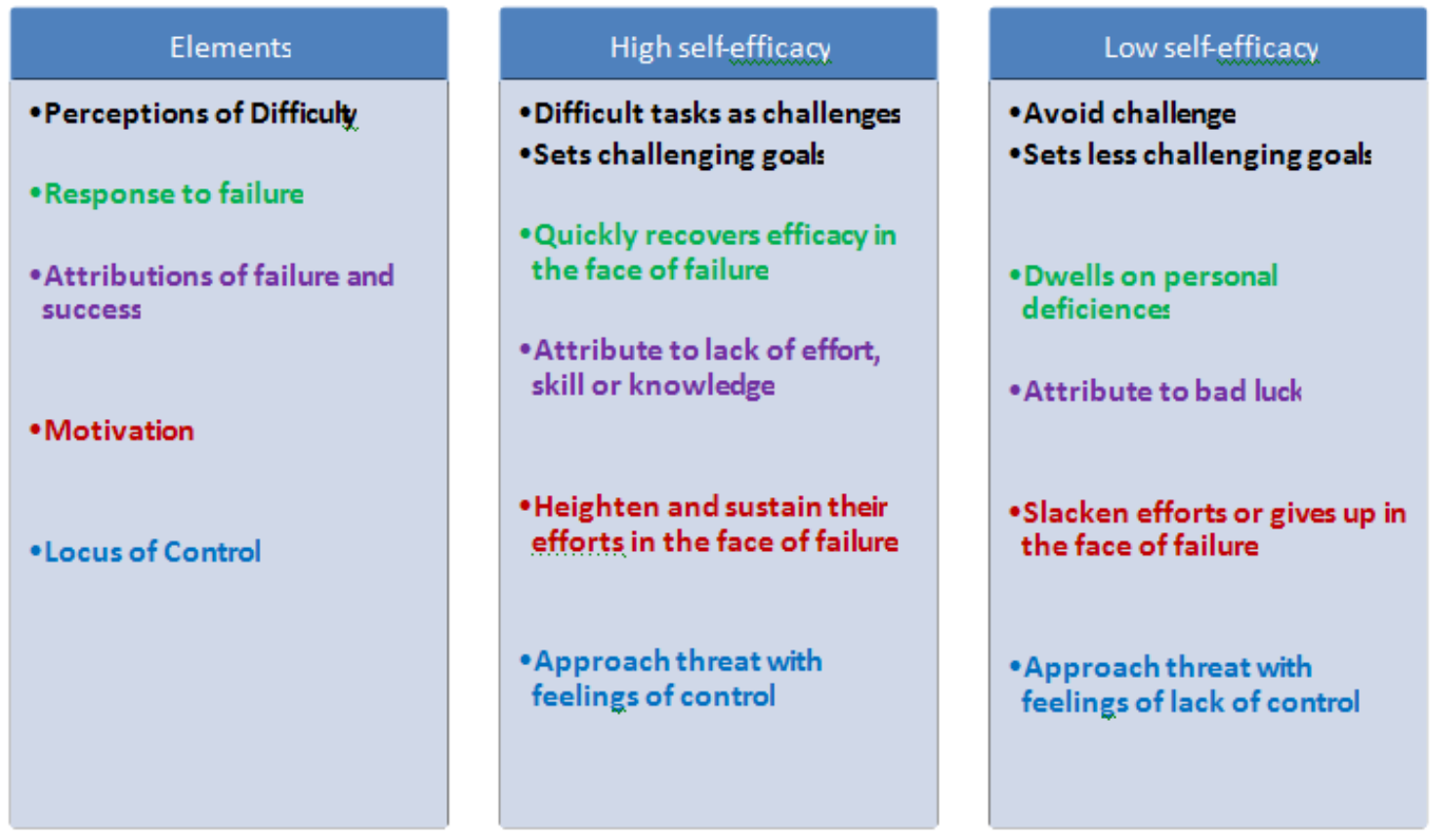

Figure 1. Bandura's Self-efficay Characteristics

When students evaluate their skills and capabilities, the resulting assessment can translate into a move to action for them or inaction. High self-efficacy students may take action because they've had some prior success and they expect to be successful again. They are more likely to engage in self-regulatory behaviors to succeed. Research has shown that prior achievement considerably influences later achievement (Adams \& Singh, 1998, Winter). Low self-efficacy students may not take action because they don't feel they are capable of performing. Consequently, they are less likely to engage in self-regulatory behaviors. A lack of success will probably diminish their likelihood to engage in these behaviors in the future.

There are numerous factors that may have a negative effect on African American and Hispanic student self-efficacy. Fordham and Ogbu (1986) suggested that African American students often doubt their abilities and logically, their doubts about their abilities may affect their self-efficacy. Tatum (1997) theorized that some African American students have nega- 
tive views about high academic achievement, believing it to be inconsistent with cultural stereotypes. Fordham and Ogbu (1986) postulated that some African American students did not want to be perceived as being too smart or acting White. Vick and Packard (2008) found that self-efficacy was an important predictor of Hispanic student achievement. Results of a 40,000 student minority network survey, that was conducted by Gewertz (2002), concluded that African American and Hispanic participants did their homework and understood their assignments less often than White and Asian students.

Self-regulation is very important for African American and Hispanic students. Yang (1993), for example, found that self-regulated learners tended to maintain greater control over their work, monitoring and evaluating as they managed their learning. Similarly, Schunk and Zimmerman (1994) suggested that self-regulated learners are more likely to have higher levels of motivation and achievement than students who do not self-regulate. We propose those students with high self-efficacy and who use more self-regulatory behaviors are less likely to be underprepared and need postsecondary remediation; early identification of students who do not possess these characteristics is important.

\section{Early Identification and Intervention of Potential Underprepared Students}

Low self-efficacy students could benefit from training in the development of high selfefficacy and more use of self-regulatory behaviors early in secondary school. The purpose of this study is to examine a means of identifying underprepared students by analyzing their perceptions of self-efficacy and their self-reported use of self-regulatory behaviors. This study compares the use of self-regulatory behaviors used by African American and Hispanic students with high self-efficacy to those with low self-efficacy. Self-efficacy has been described as an essential component for successful learning (Zimmerman, 2000). Students with higher self-efficacy use more effective learning strategies, and exhibit more self-regulated skills than those who have lower self-efficacy (Pintrich \& DeGroot, 1990; Zimmerman, Bandura, \& Martinez-Pons, 1992). Low self-efficacy students may need some intervention, This supposition is based on earlier work conducted that postulates that students who use self-regulatory behaviors generally had higher levels of academic achievement,, whereas students who use less self-regulatory behaviors consequently, had comparatively lower levels of achievement (Howard-Rose \& Winne, 1993). The results of numerous educational research studies have found positive relationships between self-regulated learning behavior and academic perfor- 
mance (Bail, Zhang, \& Tachiyama, 2008; Bembenutty, 2008; Orange, 1999; Pintrich \& DeGroot, 1990).

Analyzing where low self-efficacy students and high self-efficacy students differ in their self-reported use of self-regulated behaviors and strategies will provide useful information for educators who wish to encourage low self-efficacy students to use more selfregulatory behaviors and make it possible to identify those that may benefit from early identification and self-regulation intervention. Early identification would facilitate intervention that could improve achievement and possibly reduce the need for postsecondary remediation. Once low self-efficacy students are identified and it is known that they use less self-regulatory behaviors, teachers can intervene and help students construct meaning of what it means to be a more self-efficacious, self-regulated student. To identify students in need of self-regulation intervention, this study will use self-efficacy as a factor in the use of self-regulatory behaviors to determine whether Discriminant Analysis (PDA) can be used to classify high, moderate and low self-efficacy students by their scores on the Learning and Study Strategies Inventory for High School (LASSI-HS) and the Self-Regulation Inventory for High School (SRI-HS).

\section{The research hypothesis}

Our hypothesis is that students with low self-efficacy will use fewer self-regulatory behaviors than students with higher self-efficacy. The following, three research questions are addressed in this study:

1) Will African American and Hispanic students with low self-efficacy exhibit statistically significant lower participation in self-regulatory behaviors and strategies than African American and Hispanic students with higher self-efficacy?

2) Will student responses to the SRI-HS and LASSI-HS inventories reveal specific areas of weakness in self-regulatory activities and behaviors?

3) Can the individuals in the self-efficacy groups be correctly classified into three categories of high, moderate and low self-efficacy, based on their scores on the SRI-HS and LASSI-HS inventories? 


\section{Method}

\section{Participants}

There were originally 150 participants in the study from a predominantly African American and Hispanic High School in South Texas. Only $63\left(10^{\text {th }}[\mathrm{n}=31]\right.$ and $\left.11^{\text {th }}[\mathrm{n}=32]\right)$ of the participants returned their parent permission slips on the day of the assessment and were eligible to participate in the study. The school allowed all 150 of the participants to complete the inventories, but they only released the sixty-three that had permission slips with a promise to release the others as soon as the slips were returned. The remaining inventories were never retrieved. The participants were 52.5\% African American, 44.3\% Hispanic. All others comprised $3.2 \%$ of the group. The ages ranged from 14 to 17 years. Eighty percent of the students were between 15 and 16 years old. The group was $48.4 \%$ female and $51.6 \%$ male. Most of the students were from neighborhoods of families identified as low socioeconomic status. All participants were treated ethically in compliance with the ethical standards and code of conduct of the American Psychological Association. A larger sample would be ideal, therefore we recommend caution in interpretation and generalizability of the results.

\section{Measures}

Two measures, the Self-Regulation Inventory for High School [SRI-HS] (Orange, 1999) and the Learning and Study Strategies Inventory for High School [LASSI-HS] (Weinstein \& Palmer, 1990) were used in this study to provide a more comprehensive means of assessing self-regulation. Although both measures are designed to assess student attitudes and use of learning behaviors and strategies, each measure approaches that task in a slightly different way. They complement each other because each measure also may contain some items that are not included in the other. The LASSI-HS (Weinstein \& Palmer, 1990) features 10 scales that assess attitude, concentration, motivation, time management, anxiety, information processing, selecting main ideas, study aids, self-testing, and test strategies. The internal reliability is good; the coefficient alpha for the LASSI-HS scales are .74, .78, .77, .82, .82, .80, $.71, .68, .74, .81$, respectively. The inventory features 76 statements about learning and studying. Students are instructed to mark each statement from one of the following choices: (a) not at all like me, (b) not very much like me, (c) somewhat like me, (d) fairly much like me, (e) very much like me. 
The SRI-HS (Orange, 1999) features 50 Likert-type items on a five-point scale that are designed to assess a student's self-regulatory attitudes and behaviors. These self-regulatory attitudes and behaviors are grouped into 7 categories: self-efficacy, study strategies, selfmonitoring, self-motivating, group work, help-seeking and managing distractions. The student respondents were asked to rate these statements according to their agreement with the degree to which each statement applied to them, where a 5 is strongly agree, 4 is agree, 3 is undecided, 2 is disagree and 1 is strongly disagree. The theoretical basis of the SRI is derived from several previously identified subprocesses of self-regulation found in the literature. A Confirmatory Factor Analysis confirmed the theoretically derived latent construct of selfregulation as measured by the SRI-HS (Orange, 1999). This CFA established that the SRI-HS has adequate construct validity for purposes of this study it measures what it is supposed to measure. Good model fit indicated good factorial validity for this data. A reliability analysis of the SRI-HS indicated high reliability (coefficient alpha $=.91$ ), meaning that only $9 \%$ of the differences in the performance of the groups reflected random error (Friedenberg, 1995).

\section{Procedure}

The LASSI-HS and the SRI-HS were administered to 150 students in one session. The students were from three, different classes; after testing some of the students in one class, we moved to the other classes to test the remaining students. A total of 63 students completed the inventories and provided parent permission slips. The student respondents were asked to rate the inventory statements according to their agreement with the degree to which each statement applied to them.

\section{Statistical Analysis}

\section{Analysis of SRI-HS and LASSI-HS Responses using the Kruskal-Wallis}

Data from the SRI-HS and LASSI-HS were analyzed using the Kruskal-Wallis, a nonparametric statistical procedure that is appropriate for small samples. The Kruskal-Wallis was used to test the significance of differences in self-regulation scores to determine if selfregulation scores were higher for the high self-efficacy group than the moderate and low selfefficacy groups. Table 1 depicts a list of SRI-HS items where lower self-efficacy student responses were significantly lower than higher self-efficacy student responses. 
Table 1 . Items on the Self Regulation Inventory (SRI-HS) where Low self-efficacy African American and Hispanic Students Scored Significantly Lower than Similar High Self-efficacy Students.

There is no course that I can't pass.

$.05 * *$

I time myself when studying to make sure I have time for each subject. $.01 * * *$ I watch myself so that I don't waste time on unimportant things. when I am studying.

If I perform well on a test or assignment, I usually treat myself to something nice.

I set high standards for my work and I always try to make sure that my work meets my standards. I usually take notes in class.

I usually look at someone else's notes if I miss notes during class.

I try to study where I can minimize the number of interruptions.

Table 2 depicts a list of LASSI-HS items where lower self-efficacy student responses were significantly lower than higher self-efficacy student responses.

Table 2. Areas on the LASSI-HS Where Low Self-Efficacy African American and Hispanic Students Scored Significantly Lower Than Similar Moderate and High Self-Efficacy Students

ATTITUDE - (receptive to learning new information)

MOTIVATION- (willingness to exert effort to succeed)

TIME MANAGEMENT- (use time wisely)

ANXIETY- (concern about performance)

CONCENTRATION- (ability to focus and sustain attention)

INFO PROCESSING- (thought processes and retention of information)

SELECT MAIN IDEA- (ability to construct meaning)

STUDY AIDS- (appropriate use of materials and study strategies)

SELF-TESTING- (appropriate use of reviews, tutorials, guides)

TEST STRATEGIES- (prepare for and demonstrate new knowledge)
$.007 * * *$

$.005 * * *$
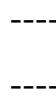

$.009 * * *$

$.012 * * *$

$.051 * *$

$.068 *$

$* * * \mathrm{p}<.01 ; * * \mathrm{p}<.05$ 


\section{Predictive Discriminant Analysis (PDA) of Student Self-efficacy}

In this study, PDA was used to determine if students could be classified by level of self-efficacy (high, moderate or low). High, moderate and low self-efficacy levels were determined by student responses to the following self-efficacy questions from the SRI-HS.

1. I can accomplish anything I try.

2. I can make a high score on any test when I try hard enough.

3. There is no course that I can't pass

4. I am a very good student.

The predictive classification is based on responses to the SRI-HS and LASSI-HS. The classification grouping variable is identified as self-efficacy (labeled Self-Perception), which in this study is defined as an ordinal, categorical variable, with the following exhaustive and mutually exclusive levels: High Self-Efficacy, Moderate Self-Efficacy, and Low SelfEfficacy. The selected classification predictor variables are summated rating scale scores from SRI-HS and LASSI-HS questionnaires. The subprocesses represented in each instrument are indicated below:

1) SRI-HS: Help-Seeking, Managing Distractions, Self-Monitoring, Self-Motivating, SelfPacing, and Group Work

2) LASSI-HS: Anxiety, Attitude, Concentration, Motivation, Self-Testing, Selecting Main Idea, Study Aids, Time Management, and Test Strategies

\section{Results}

The results of the Kruskal-Wallis indicate a yes for the research question 1, concluding that African American and Hispanic students with low self-efficacy exhibited statistically significant lower participation in self-regulatory behaviors and strategies than African American and Hispanic students with higher self-efficacy. The results also indicate a yes for research question 2, concluding that student responses to the SRI-HS and LASSI-HS inventories revealed specific areas of weakness in self-regulatory activities and behaviors where lower self-efficacy student responses were significantly lower than higher self-efficacy students. The results of both inventories revealed specific areas of weakness, such as problems in managing distractions, attitude, concentration, help-seeking, study strategies, goal setting, attention, selecting the main idea and test strategies. In terms of group performance, mean scores 
for most of the groups were at the $50^{\text {th }}$ percentile or lower on almost all 10 of the LASSI-HS scales (see Table 3 for group percentiles).

Table 3. Mean Scale Scores and Percentiles on the LASSI-HS

SCALE

MEAN SCORE N=63

PERCENTILE

ATTITUDE

MOTIVATION

TIME MANAGEMENT

ANXIETY

CONCENTRATION

INFO PROCESSING

SELECT MAIN IDEA

STUDY AIDS

SELF-TESTING

TEST STRATEGIES
24

28

21

24

25

27

16

24

25

26
15

40

50

50

50

60

45

60

50

45

Attitude was at the very low $15^{\text {th }}$ percentile for both groups, indicating that attitude is a serious problem for most of the students in this study. The attitude scale attempts to assess if students see school as important and worthwhile, if students have clear educational and future goals and if school is merely a means of getting a job. The Attitude scale is significantly, positively correlated with every other scale on the LASSI-HS except study aids. Carver, Sutton and Scheier (2000) argued that individuals will manage or avoid future tasks according to their positive or negative past experiences.

The results of the PDA indicates a yes for the third research question that individuals in the self-efficacy groups can be correctly classified into three categories of high, moderate and low self-efficacy, based on their scores on the SRI-HS and LASSI-HS inventories. A limitation of the study was that some of the students did not return permission slips and the school district would not release their inventories which resulted in a much smaller sample size than anticipated. The limitation of the smaller sample used in this study, make further study with a larger sample highly desirable and suggests using caution in generalizing the 
results of this study. No distinctions were made between African American and Hispanic participants, their scores were reported as a group. Therefore results of this study on the level of self-efficacy and self-regulation of the participants were reported collectively.

\section{Predictive Discriminant Analysis Classification Results}

Discriminant Function Analysis (DFA) classifies cases into the values of categorical dependent variables. If the classification is done correctly, the classification table of correct and incorrect estimates will yield a high percentage of correct classifications. In this Discriminant Function Analysis, $72.9 \%$ of original grouped cases were correctly classified (see Table 4 for group classifications).

Table 4. Group Classification Results

\begin{tabular}{|c|c|c|c|c|c|}
\hline \multicolumn{2}{|c|}{ Self Perception } & \multicolumn{3}{|c|}{ Predicted Group Membership } & \multirow[t]{3}{*}{ Total } \\
\hline & & High & Moderate & Low & \\
\hline & & Self-efficacy & Self-efficacy & Self-efficacy & \\
\hline \multirow[t]{4}{*}{ Original Count } & High Self-efficacy & 17 & 3 & 1 & 21 \\
\hline & Moderate & 4 & 13 & 3 & 20 \\
\hline & Self-efficacy & & & & \\
\hline & Low self-efficacy & 2 & 3 & 13 & 18 \\
\hline \multirow[t]{4}{*}{ Percent \% } & High Self-efficacy & 81.0 & 14.3 & 4.8 & 100.00 \\
\hline & Moderate & 20.0 & 65.0 & 15.0 & \\
\hline & Self-efficacy & & & & \\
\hline & Low Self-efficacy & 11.1 & 16.7 & 72.2 & \\
\hline
\end{tabular}

$72.9 \%$ of original grouped cases correctly classified

Seventeen out of 21 cases or $81 \%$ of the high self-efficacy group was correctly classified as high self-efficacy; three cases in this group were incorrectly classified as moderate self-efficacy and 1 was classified as low self-efficacy. Thirteen out of 20 cases or $65 \%$ of the moderate self-efficacy group was correctly classified as moderate self-efficacy; four cases in this group were incorrectly classified as high self-efficacy and 3 as low self-efficacy. Thirteen out of 18 cases or $72 \%$ of the low self-efficacy group was correctly classified as low self- 
efficacy, 3 cases were incorrectly classified as moderate and 2 as high self-efficacy. Only 59 of the sixty-three cases were used in the analysis due to missing data in 4 cases.

\section{Test of the Discriminant Functions}

The Wilk's Lambda tests the significance of the discriminant function as a whole. It was used to test the null hypothesis that the means of the three groups are equal on the discriminant functions. The overall Wilk's Lambda of .392, $p<.05$, was significant. The small lambda of .392, is closer to 0 , meaning the groups differ, as reflected in a significant $p$ value of $.032<.05$. The group centroids in Figure 2 are mean discriminant scores for each of the dependent variable categories for each of the discriminant functions (see Figure 2 for a graphic depiction of the discriminant functions).

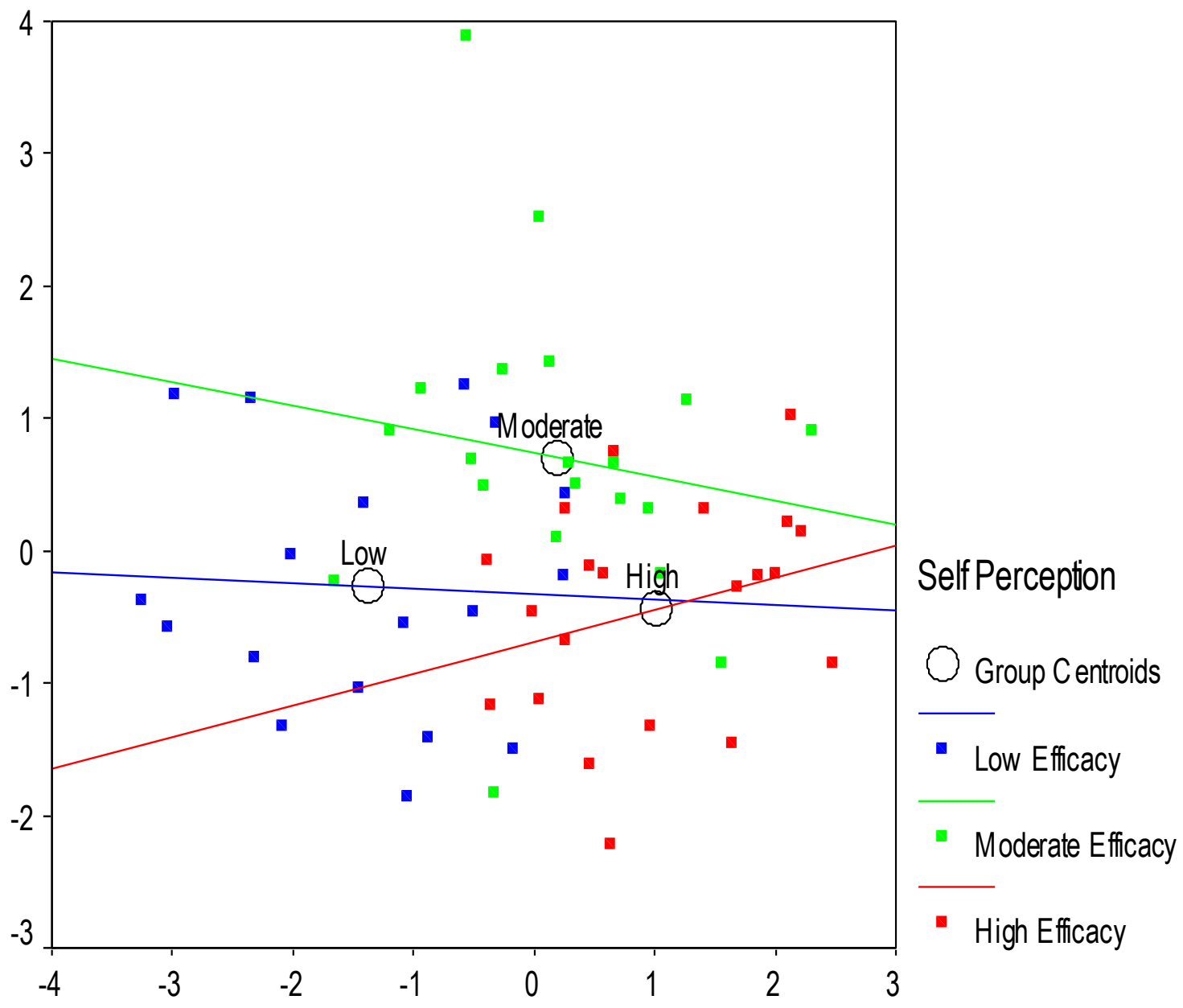

Function 1

Figure 2. Separation of group by discriminant 
In this analysis, the means are far apart, indicating less likelihood of classification error. Results indicate that there are significant differences between the group means. Therefore, we can conclude that the model is discriminating between the groups significantly better than chance.

\section{Eigenvalues and Effect Size}

The eigenvalue reflects the ratio of importance of the dimensions which classify cases of the dependent grouping variable. In this analysis, $78.8 \%$ of the variance is explained by the first function, which usually accounts for more between group variance in the dependent categories than does the second discriminant function. Self-efficacy (self-perception) is the grouping variable and the 3 categories are high self-efficacy, moderate self-efficacy and low self-efficacy. Effect size may be determined by Eigenvalues. The values $.01, .06$, and .14 usually represent a small, medium and large effect size respectively (Green, Salkind \& Akey, 2000). For the first and second functions, the squared canonical correlation is .503 and .21 respectively; both suggest a large effect size.

\section{Discussion}

Fall \& McCleod (2001) contend that recognizing inefficacious students and knowing their areas of weakness is the key for improving the self-efficacy for all students. The Predictive Discriminant Analysis model developed in this study will be useful for that purpose in that it can classify students that have low self-efficacy and that may be in need of intervention to increase their use of self-regulatory behaviors. An implication for educators is that a high perception of self-efficacy is critical for African American and Hispanic student academic success if they are to be better prepared for college and avoid postsecondary remediation.

It is also important for educators to address the academic weaknesses of low selfefficacy students identified in this study such as managing distractions, attitude, concentration, help-seeking, study strategies, goal setting, attention, selecting the main idea and test strategies. As previously mentioned, Gewertz (2002) contends that African American and Hispanic youth do less homework and have difficulty understanding homework due to an inability to manage distractions, which is a significant academic weakness, that can be corrected. It is imperative to teach and encourage students to use self-regulatory behaviors and to have a good attitude. When students are positive, optimistic and confident about their ability to handle a learning situation, they tend to have high self-efficacy. If they have doubts about their 
capabilities or a lack of confidence, they tend to have low self-efficacy, characterized by avoiding challenges and fear of difficult work.

One contributor to the attitude score being at the low $15^{\text {th }}$ percentile for high and low self-efficacy students is peer pressure. Peers may inadvertently impede the achievement of various racial or ethnic groups by stigmatizing their achievement efforts with negative labels such as "nerd", "geek" or “oreo" (Witherspoon, Speight \& Thomas, 1997). This consequent stigmatization of achievement may help to explain the lower scores on the SRI-HS items that require help-seeking or interacting with peers for information, notes and so on. Students may not want other students to think they are trying to be smart. Ogbu (2003) argues that African American youth may view academic achievement as acting White, or not being Black. If Ogbu is correct, these students may deliberately sabotage their academic achievement. Becker and Luthar (2002) cite peer values as a significant socio-emotional factor that affects student achievement.

Lewis (2003) offers some explanation of why the high self-efficacy students have such a low attitude toward school, saying they apparently entertain an anti-school attitude but fail to act on it. This is evidenced by their use of self-regulatory behaviors. High self-efficacy students believe they can be a good student, they just don't want to, although they will probably do it anyway. Perhaps forces such as parental pressures or other expectations inspire them to persevere as they work in what they perceive as less than optimal educational environments-poor schools, low teacher expectations and minimal resources. Unfortunately, the low self-efficacy group may not have the psychological wherewithal to withstand the onslaught of thoughts, emotions and perceptions about their educational self-efficacy. They must perceive they can do it before they do it. They are probably unable to be self-regulating enough to succeed in spite of their low attitudes, as their peers with higher self-efficacy seem to be able to do.

Clearly, all of the students in the study could benefit from some form of attitude, selfefficacy, and self-regulation intervention. The following recommended, self-efficacy exercise may be useful for improving student attitudes toward school, encouraging self-regulated behaviors, improving student perceptions of participation, teaching appropriate attribution of successes and failures, and for diminishing the stigma of counseling and tutoring, that can help students develop a more efficacious attitude: 


\section{A Recommended Self-efficacy Exercise}

1. Using a self-efficacy measure of your choice, strategically pair low self-efficacy students as the interviewers with high self-efficacy students as the interviewees to discuss what attitudes and behaviors makes a student successful enough to stay in school, make better grades and graduate.

2. Have low self-efficacy students ask high self-efficacy students the following questions that are based on the Bandura (1986) characterization of low self-efficacy students, assuming that the responses from the high self-efficacy students will be inspiring and motivating.

- What motivates you to stay in school?

- What do you do if you feel like you want to quit?

- How do you build self-confidence?

- Is there anyone that makes you want to work hard in school? Why?

- What are your plans after graduation?

- $\quad$ How do you cope and make yourself feel better and keep working when you fail or you make mistakes?

- What keeps you going when you feel like giving up?

- How do you feel about doing difficult things?

- What makes you try to do them even though you know they are difficult?

- Do you ever feel like you are afraid to try to do something because you might not be able to control what happens? What helps you to do it anyway?

- $\quad$ Do you feel you work hard or do you think you are just lucky?

- What are some strategies you use to study and make good grades?

3. Low self-efficacy students should switch and interview at least 2 other high selfefficacy students. As a group, students will build a profile of a successful student from the comments they have heard, on poster sheets. The teacher, as a facilitator, will help the group to construct a profile of high self-efficacy students and at this point tell them what characterizes high self-efficacy and low self-efficacy. Teachers will facilitate further by helping students checklist their strengths and areas that need improvement. 
4. The teacher can further the process by inviting students to help her to understand some of their concerns and opinions of school. A student's frame of mind or feelings about learning and their willingness to learn may be a reasonable definition of attitude. For example if a student said "Teachers are only teaching for the money". The teacher's response to student comment might be: "I know that some students think we are only teaching for the money, that's not true, I want you to succeed. I did not become a teacher to get rich. I became a teacher because I care about my students and I want to help them to learn."

5. Once all concerns are addressed, The teacher will then help students to create an action plan that uses new ideas and information and discards old thoughts and ideas that may present obstacles to learning, and a good attitude toward school.

6. The teacher can help all students focus on using self-regulatory strategies, with a particular emphasis on self-regulatory behaviors such as help-seeking, attention, study skills and strategies, goal-setting, managing distractions, concentration, and selecting the main idea, all areas of identified deficiencies. To promote help-seeking, educators should try to be as approachable as possible and encourage students to work together in study groups, exchange phone numbers, compare notes and/or exchange notes. Teachers can improve the classroom learning environment by: making it more conducive to asking questions, tolerating student mistakes, offering gentle criticism, Teachers should teach study skills and strategies, Teachers can help students learn to sustain goal-directed behaviors by giving sporadic motivational pep talks that are focused on attribution, effective study strategies, encouragement, personal affirmations, test-taking strategies and self-motivation.

This recommended exercise can be modified as necessary to fit different educational situations. The contribution of this study to the literature is that it offers a predictive model for classifying students based on self-efficacy; identified deficiencies in self-regulatory behaviors and strategies for African American and Hispanic students and a recommend selfefficacy exercise that has the potential to move students towards being more self-regulated learners with higher self-efficacy and better attitudes, which will hopefully translate into higher achievement, better preparation for college and a reduction in their need for postsecondary remediation. One of the limitations of the study is that the sample size is smaller than we had planned. Only 63 of the 150 students that were assessed were eligible to participate because we were only given access to assessments from student who returned their parent 
permission slips. The school kept the remaining assessments, waiting for students to bring their slips. Unfortunately, the school was moving some offices and the remaining assessments and additional permission slips were never recovered. Both self-regulation measures were self-report which limits independent verification of the data.

The limitations of the study suggest a need for a larger sample size; the sample size of 63 was adequate but caution is recommended in generalizing the data. When collecting selfreport data, further research such as encouraging participants to also participate in focus groups, may be useful for verification of the data.

\section{Acknowledgements}

The authors want to thank Drs. Norma Guerra and Pei-Hsuan Hsieh for their comments on an earlier draft of this manuscript.

\section{References}

ACT, I. (2012). The Condition of College \& Career Readiness 2010, from http://www.act.org/research/policymakers/cccr10/index.html

Adams, C. R., \& Singh, K. (1998, Winter). Direct and indirect affects on school learning variables on the academic achievement of African American 10th-graders. The Journal of Negro Education, 67,48-66.

Bail, F. T., Zhang, S., \& Tachiyama, G. T. (2008). Effects of a self-regulated learning course on the academic performance and graduation rate of college students in an academic support program. Journal of college reading and learning, 39, 54-73.

Bailey, T. (2009). Challenge and opportunity: rethinking the role and function of developmental education in community college. New directions for Community Colleges, 145, 11-30.

Bailey, T., Jeong, D. W., \& Cho, S. W. (2009). Referral, enrollment and completion in developmental education sequences in community colleges., (Community College Center Research Working Paper 15.). Columbia University.

Bandura, A. (1977). Social learning theory. New York: General Learning Press.

Bandura, A. (1986). Social foundations of thought and action: A social cognitive theory. . Englewood Cliffs, NJ: Prentice-Hall.

Bandura, A. (1994). Self-efficacy. In V. S. Ramachaudran (Ed.), Encyclopedia of human behavior (pp. 71-81). New York: Academic Press. 
Bandura, A. (1997). Self-efficacy: The exercise of control. . New York, NY: W.H. Freeman.

Becker, B. E., \& Luthar, S. S. (2002). Social-emotional factors affecting achievement. Educational Psychologist 37, 197-214

Bembenutty, H. (2008). Self-regulation of learning and test anxiety. Psychology Journal, Five(Three), 122-139.

Breneman, D. W. (1998). Remediation and higher education: is the extent and cost. Brookings Papers on Education Policy, 1, 359-383.

Carver, C. S., Sutton, S. K., \& Scheier, M. F. (2000). Action, emotion, and personality: Emerging conceptual intergration. Personality and Social Psychology Bulletin, 26 741-751.

Davis, R. J., \& Palmer, R. T. (2010). The Role of postsecondary remediation for African American students: A review of research. . Journal of Negro Education, 79(4), 503520.

Fall, M., \& McLeod, E. H. (2001 ). Identifying and assisting students with low self-efficacy. . Professional School Counseling 334-341.

Fordham, S., \& Ogbu, J. (1986). Black students' school success: Coping with the burden of acting White. Urban Review 18 1-31.

Friedenberg, L. ( 1995). Psychological testing: Design analysis and use. Needham Heights, MA Allyn \& Bacon.

Gewertz, C. (2002). No racial gap seen in students' outlook. . Education Week, 22, 5.

Green, S. B., Salkind, N. J., \& Akey, T. M. (2000). Using SPSS for windows, analyzing and understanding data. . Upper Saddle River, NJ Prentice Hall.

Howard-Rose, D., \& Winne, P. H. (1993). Measuring components and sets of cognitive processes in self-regulated learning. Journal of Educational Psychology 85, 591-604.

Jackson, J. W. (2002). Enhancing self-efficacy and learning performance. The Journal of Experimental Education, 70, 243-255.

Lane, J., \& Lane, A. (2001 ). Self-efficacy and academic performance. . Social Behavior and Personality, 29, 687-694.

Melguizo, T., Hagedorn, L. S., \& Cypers, S. (2008). Remedial/developmental education and the cost of community college transfer: a Los Angeles County sample. Review of Higher Education, 31(For), 401-431.

NCES. (2010). Table 241. Percentage of first-year undergraduate students who took remedial education courses, by selected characteristics. Washington, D. C.: National Center for Educational Statistics. 
NCSL. (2012). Improving College Completion - Reforming Remedial Education Retrieved 11/20/2012, 2012, from http://www.ncsl.org/issues-research/educ/improving-collegecompletion-reforming-remedial.aspx

Ogbu, J. (2003). Black American students in an affluent suburb: A study of academic disengagement. Mahwah, New Jersey: Lawrence Erlbaum Associates.

Orange, C. (1999). Using peer models to teach self-regulation. Journal of Experimental Education, The eighth, 21-31.

Pajares, F. (2003). Self-efficacy beliefs, motivation, and achievement in writing: A review of the literature. Reading and Writing Quarterly, 19, 139-158.

Pajares, F., \& Miller, M. D. (1994). Role of self-efficacy and self-concept in mathematical problem solving: A path analysis. Journal of Educational Psychology, 86, 193-203.

Pintrich, P., \& DeGroot, E. V. (1990). Motivational and self regulated learning components of classroom academic performance. Journal of Educational Psychology, 82(33-40.).

Schunk, D. H. (1991). Self efficacy and academic motivation. Educational Psychologist, 26, 207-231.

Schunk, D. H. (1996). Learning theories: An educational perspective. Inglewood Cliffs, New Jersey: Prentice-Hall.

Tatum, B. D. (1997). Why are all the Black kids sitting together in the cafeteria? And other conversations about race. New York: Basic books.

Tierney, W. G., \& Garcia, L. D. (2008). Preparing the underprepared students for college: Remedial education and early assessment programs. Journal of A At-Risk Issues, 14(To), 1-7.

Vick, R. M., \& Packard, B. W. (2008). Academic success strategies among community-active urban Hispanic adolescents. Hispanic Journal of Behavioral Sciences, 30, 463-480.

Weinstein, C. E., \& Palmer, D. R. (1990). LASSI-HS: Learning and Study Strategies Inventory-High School Version. Clearwater, Florida: $\mathrm{H}$ and $\mathrm{H}$ Publishing.

Witherspoon, K. M., Speight, S. L., \& Thomas, A. J. (1997). Racial identity attitudes, school achievement, and academic self efficacy among African-American high school students. Journal of black psychology, 23, 244-257.

Zimmerman, B. J. (1989). A social cognitive view of self regulated academic learning. Journal of educational psychology, 81, 329-339.

Zimmerman, B. J. (1998). Developing self-fulfilling cycles of academic regulation: an analysis of exemplary instructional models. In D. H. S. a. B. J. Zimmerman (Ed.), From teaching to self reflective practice (pp. 1-19). New York: Guilford. 
Zimmerman, B. J. (2000). Self-efficacy: An essential motive to learn. Contemporary educational psychology, 82-91.

Zimmerman, B. J., Bandura, A., \& Martinez-Pons, M. (1992). Self motivation for academic attainment: The role of self-efficacy beliefs and goal setting. American educational research Journal, 29, 663-676.

Zimmerman, B. J., \& Martinez-Pons, M. (1990). Student differences in self regulated learning: relating grade, sex and giftedness to self-efficacy and strategy use. Journal of educational psychology, 82, 51-59. 